\title{
Enhancing EFL Secondary Stage Students' Listening and Reading Comprehension Skills through a CALL Program
}

\section{Mohammed Mohammed El-Sayed , Prof. Aly Abd Samea Qoura , Asso. Prof. Mervat Mohamed Saleh El-Hadidy} Mansoura University, Faculty of Education, Department of Curriculum \& Instruction

\section{ABSTRACT:}

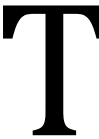

his study aimed at investigating the effectiveness of a CALL program in developing listening and reading comprehension skills of first year secondary stage students. To accomplish this purpose, the researcher constructed and validated a listening comprehension test and a reading comprehension test. The participants were two classes (60 students) from first year secondary stage students at Ahmed Shelbia Secondary School for Girls, Manzala Directorate. They were randomly selected and equally divided into an experimental group and a control group. Both groups were pre-tested. After ensuring their equivalence, the experimental group students were taught reading and listening using the CALL program, meanwhile the control group students were taught according to the teaching procedures in the Teacher's Guide assigned by the Ministry of Education. After teaching the program, both groups were posttested using the same instruments utilized in the pre-testing. Findings of the study indicated significant differences between the mean scores of the experimental group and those of the control group on the post listening comprehension test and post reading comprehension test in favour of the experimental group.

Key words: CALL, listening comprehension and reading comprehension

\section{Introduction:}

The worldwide need for English has established a growing desire for effective language teaching and language teaching materials and resources. Learners of English need to have a full command of English to a high level of accuracy and fluency. Hence, the need for an effective teaching methodology is increasing. The significance of CALL was highlighted in Prensky (2000) who reported that at the present time, students admit that a world without computers, media or the internet is 
considered meaningless. Moreover, Bax, (2003) went on saying that CALL should be regarded as a normal component of the English language classroom.

Listening has an outstanding role in life. Children listen before they learn any other skills. In the classroom, students have to listen carefully to their teachers. So, according to Boyle (1993) listening is a crucial skill for learners as it is the first skill used while learning a language

Reading is a gateway to a world of fun and learning. But, it is considered a complex process which entails some operations. Reading becomes more complicated when the text is in a second or a foreign language. Egbert (2005) stated that many variables play a part in L2/FL reading comprehension. Among the most important are L1 literacy, the use of both top-down and bottomup strategies, activating background knowledge, the use of various reading skills.

\section{Statement of the Problem:}

A major area of weakness of Egyptian secondary students is that of reading and listening comprehension skills. This weakness in reading comprehension was asserted by Eissa (2009) and Mattar (2006) and in listening comprehension by Hassan (2013), and Abdelhafez (2006). Also, out the researcher experience as an EFL teacher for 19 years, it has been noticed that first year secondary students encounter difficulties in both reading and listening comprehension. To document the problem of the present study, the researcher conducted a pilot study to investigate first year secondary students' actual level in reading and listening comprehension. The results in (Table 1) indicated that there is a weakness in reading and listening comprehension.

Table (1) Scores of the Sample on both the Reading and Listening Comprehension Tests

\begin{tabular}{|c|c|c|}
\hline The tests & $\begin{array}{c}\text { Reading } \\
\text { comprehension }\end{array}$ & $\begin{array}{c}\text { Listening } \\
\text { comprehension }\end{array}$ \\
\hline The mean score & 2.1 & 4.6 \\
\hline The standard & 1.5 & 2.1 \\
\hline deviation & 10 & 10 \\
\hline Total marks & 10 & \\
\hline
\end{tabular}




\section{Objectives:}

1. This study aims at improving listening and reading comprehension skills of first year secondary stage students using CALL.

2. It aims at investigating the effectiveness of the suggested program in improving listening and reading comprehension skills.

\section{Questions:}

The main question of the study is :

What is the impact of the proposed CALL program on developing listening and reading comprehension skills among first year secondary stage students? Out of this question, the following sub-questions are asked :

1. What is the current level of first year secondary stage students in listening comprehension and reading comprehension?

2. How far is the suggested program effective in developing listening comprehension, reading comprehension among first year secondary stage students?

\section{Hypotheses of the Study:}

The following hypotheses are formulated:

1. There is a statistically significant difference between the mean scores of the experimental group and those of the control group on the post test of listening comprehension favoring the experimental group.

2. There is a statistically significant difference between the mean scores of the experimental group and those of the control group on the post test of reading comprehension favoring the experimental group.

\section{Significance:}

1. 1. This study will determine the impact of a CALL program on developing listening comprehension and reading 
comprehension among first year secondary stage students.

2. 2. It will raise teachers' awareness of a multimedia - based program to teach listening comprehension and reading comprehension among first year secondary stage students.

\section{Delimitations:}

The present study is delimited to:

1. A sample of first year secondary stage students in Manzala Directorate, Dakahlia.

2. The reading passages in the textbook of first year secondary stage students.

\section{Design of the Study:}

\section{The Sample:}

The sample of the present study will be a random sample of 60 students of first year secondary stage students. They will be divided into two groups ( the control group ) of 30 students to be taught reading and listening comprehension in the traditional methods ,the second group of 30 students ( the experimental group) to be taught using the proposed multimedia program.

\section{Instruments:}

1. A pre-post listening comprehension test to measure students' level in listening comprehension before and after the intervention.

2. A pre-post reading comprehension test to measure students' level in reading comprehension before and after the intervention.

\section{Definition of Terms:}

\section{CALL:}

For Levy (1997), it is the search for and study of programs of the computer in English language learning and teaching. CALL is defined operationally as the utilization of various media forms such as text, graphic, pictures and sound to select and use 
information to help students develop their reading comprehension and listening comprehension.

\section{Listening Comprehension:}

O'malley and Chamot (1989) showed that listening comprehension is an active and conscious process in which listeners construct meaning through using cues from contextual information and existing knowledge while depending on various strategies. Operationally, it is the competence of mastering the two domains: bottom-up, by which listeners can decode sounds and top-down, by which they can recognize the main idea and the details of the text.

\section{Reading Comprehension:}

Grabe (1991) defined it as an active process of comprehending where readers should be taught strategies to read effectively (guessing from context, defining expectations, making inferences, etc. For the purpose of the current study, reading comprehension is the active process in which the reader gets meaning and knowledge from the text through linguistic and schematic knowledge.

\section{Review of Literature and Related Studies:}

There have been tremendous developments in the field of technology lately. Also, there has been a corresponding growth of English. With the recent advances in science and technology, the developing of computer technology in teaching has become significant in English teaching. Beatty (2003) viewed CALL as all processes in which learners utilizes a computer and, hence, develops their language. He furthers indicated that CALL comprises material design, pedagogical theories and technologies.

\section{Background of CALL Development:}

Over years, researchers have tried to present the development of CALL. To begin with, Davies \& Higgins (1985) recognized the following types of CALL programs : gap-filling exercises, multiple-choice exercises, free-format exercises, tutorial programs, re-ordering, simulations games and writing - 
word- processing .Then, Hardisty \& Windeatt (1989) presented another classification of CALL programs which are:

1. School programexercises involving multiple-choice and matching .

2. Office programs: Microsoft Word, Excel and PowerPoint .

3. Library programs: concordancers .

4. Home programs: adventures and simulations.

Warschauer (1996) , Warschauer and Healey (1998) presented a new concept for CALL mentioning three historical stages of CALL according to their underlying pedagogical and methodological approaches. Warschauer (1996) classified such concept in three historical phases: behavioristic, communicative and integrative. Firstly, behaviouristic CALL was when the computer was utilized as a tutor: a medium for presenting instructional materials to the students. Programs based Behavioristic CALL mainly involved drill-and-practice materials .The computer role was to present a stimulus and students respond. Another stage emerged influenced by the dominance of the communicative approach. This stage was called communicative CALL .It coincided with the appearance of the personal computer. In this stage, applications were designed mainly for skill practice, but-unlike Behaviouristic CALL- in a non-drill design. Also, programs based on communicative CALL were characterized by learners' choice, control and interaction.

Integrative CALL stage has witnessed the emergence of outstanding innovations, namely, multimedia and the internet. This stage is characterized by combining teaching language skills into tasks or projects. Integrative CALL also

Coincided with the progress in multimedia, the internet and computer-mediated communication (CMC). In this stage, CALL witnessed a change of utilizing the computer for drill and tutorial aims to a medium to maintain study in beyond the classroom.

Another innovation of CALL is Web 2.0 which has taken the place of Web 1.0. O'Reilly (2005) outlined that Web 2.0 is the 
system that repeatedly updates information, has more people to utilize the internet, and gets and remixes data from numerous sources. The great potentialities that Web 2.0 has led to the emergence of promising tools. One of these tools is weblog or blog. For Campbell (2003), it is as an online journal which can be updated all the time by users with their ideas, and thoughts via programs that enable them to do easily that. Wikis is another outstanding Web 2.0 instrument that learners have been making use of in language classrooms. Leuf \& Cunningham (2001) perceived a wiki as a group of connected web pages or a database that can be easily expanded and edited by any user- it is a hypertext system that can store and change information .

Another application of Web 2.0 technologies is social networking. Nowadays, a lot of users publish their thoughts and communicate all over the world using social networking sites O'Reilly (2005). Social networking sites such as Facebook, Friendster, and Twitter etc. give impressive chances for people to contact with each other and share their thoughts.

The field of CALL is expanded to comprise using mobile in language learning. This field is known as Mobile Assisted Language Learning (MALL) which is, according to Valarmathi (2011), making use of any handheld mobile devices in language learning. She considers MALL as a "subset" of Mobile Learning and CALL.

\section{Studies Related to CALL:}

In her study, Ali (2016) utilized a CALL program for developing EFL preparatory stage students' vocabulary and grammar learning and their motivation. The study followed the quasi experimental design. To achieve the purpose of the study, she used a pre/post vocabulary and grammar achievement test; and a pre/post scale to measure students' motivation towards learning vocabulary and grammar. The results showed that: 1the proposed CALL program "Hot Potatoes" was effective in developing EFL preparatory stage students 'vocabulary and grammar learning and motivation. 
In another study conducted by Ismail (2016), he investigated the effect of educational blogs on enhancing preparatory school students' English reading comprehension skills. He used two groups: the experimental group and the control group to fulfill his purpose. The treatment group students were taught reading comprehension through the educational blogs, while the control group learnt through regular instruction. The researcher used a reading comprehension pre/post test to measure the level of students' reading comprehension skills. Findings of the study revealed that there were significant differences at 0.01 between the mean score of both groups in all the EFL reading comprehension skills on the post administration of the test in favour of the experimental group .Also, the educational blogs had a large effect on all the required EFL reading comprehension skills.

Hamed (2016) explored the impact of a proposed webbased unit (PWBU) to develop reading comprehension skills and measure the participants' attitudes towards reading on the web. The PWBU included six units (13th, 14th, 15th, 16th, 17th, and 18th) from Hello! 3 for Al-Azhar third preparatory institute students. Each unit contained two electronic-lessons, from six to seven slides as an assignment and a sound box. An attitude scale used before and after the experiment to measure students' attitudes towards reading on the web. Results revealed that there was a major improvement in reading comprehension skills and attitudes towards reading on the web for the experimental group in favor of the PWBU .

\section{Listening Comprehension:}

\section{Listening -Defined:}

There have been attempts to put what listening is .For example, Underwood (1989) cited in Radwan (2010) presented a simple definition for listening comprehension saying that it is the activity of paying attention to and attempting to acquire meaning from something heard. Also, Mendelsohn (1994) defined listening comprehension as-being able to comprehend the spoken language of native speakers. 


\section{Significance of Listening:}

Listening has a crucial role people's lives. It is at the heart of both first and second language learning. Of the four main areas of communication skills and language development-listening, speaking, reading, and writing- listening is regarded as the main skill. Children listen and respond to language before they learn to talk, read or write. Mendelsohn (1994) confirmed this fact saying that listening has a key role in communication due to the total amount of time which is spent on communication. He maintained that listening takes up 40-50\%; speaking, 25-30\%; reading, 11$16 \%$; and writing, about $9 \%$ of the time spent in communication.

\section{The Sub-Skills of Listening Comprehension:}

There have been numerous attempts to describe listening comprehension in terms of taxonomies of sub-skills. Researchers have developed various taxonomies of listening. For example, Richards (1983) cited in Radwan 2010 identified the conversational listening and academic listening. To him conversational listening refers to listening to casual speech, whereas academic listening means listening to lectures. Richards' taxonomy of micro-skills of academic listening includes the ability to:

1. Recognize purpose the lecture.

2. Recognize the role of discourse markers.

3. Make inference of relationships (e.g. cause, effect, conclusion).

4. Identify main lexical terms related to subject/topic,

5. Infer meanings from context.

As for conversational listening, Richards considered it as the ability to:

1. Keep chunks of language of different lengths for short periods

2. Discriminate among the distinctive sounds.

3. Identify the stress and the rhythmic structure of English patterns of words. 
4. Identify stress and intonation.

5. Identify reduced forms of words.

\section{Teaching Listening Activities:}

Karakas (2002) cited in Ahmadi (2011) mentioned that listening activities enhance the listeners' interpretation of the text. He subcategorized them as pre-listening, while-listening, and post-listening activities as following. Karakas pointed out that schema theory proved the effect of pre-listening activities. Instructors can explain specific words and grammatical structures through discussion. Also, they can ask students to predict what speakers are going to say. He maintained that the goal of this stage is to help students to activate their prior knowledge. He maintained that during activities aim at focusing listeners' comprehension of the spoken text and at increasing their attention. For Karakas post-listening activities are essential as they extend students' listening skills. Such activities are more effective the moment they are presented at once after the listening experience. They supply students with chances to relate what they heard to their ideas and experiences, Also, they help teachers to examine students' comprehension. Underwood (1989) lists some post-listening activities like:

1. Role play/simulation

2. Jigsaw listening

3. Summarizing

4. Dictation

\section{Listening Difficulties}

Buck (2001) identified some difficulties which students confront in listening tasks like difficult vocabularies, unfamiliar topics, fast speech rate, and unfamiliar accents. Also, Rost (1994) mentioned the common listening difficulties like:

1. The physical problems which impede listening like noise .

2. Difficulties with auditory memory (Some learners have difficulties remembering what they have just heard) and sequentional memory (Some learners have difficulties 
remembering the correct sequence of words they have just heard).

3. Attention and concentration .Some learners have problems in attention and concentration.

4. Comprehension, some learners have difficulties in literal comprehension, others in critical listening and others in evaluative listening .

\section{Studies Related to Listening Comprehension:}

Al-Ammary (2015) aimed at measuring the impact of a program based on podcasts on developing some EFL listening comprehension skills of second-year preparatory students. To accomplish this aim, the researcher constructed a questionnaire, a listening comprehension skills test and a program based on podcasts. Participants of the study comprised of two classes (60 students) .They were randomly selected and divided into an experimental group and a control one. Both groups were pretested using the listening comprehension skills test. Then, the experimental group students learnt listening using the program based on podcasts, while the control group students learnt according to the Teacher's Guide set by the Ministry of Education. After applying the program, both groups were posttested using the same tool used in the pre-testing. Results of the research indicated a significant difference between both groups on the listening comprehension skills post-test in favor of the experimental group.

Mahmoud (2015) used subtitled and non-subtitled authentic video clips based-activities for developing EFL preparatory stage students' listening comprehension skills. To achieve the aim of the study, two tools were designed: A pre-post listening comprehension test and an authentic video clips evaluation checklist. The study adopted the quasi-experimental design. The participants of the study consisted of 120 students who were randomly assigned into three groups: two experimental groups: The first experimental group was exposed to non-subtitled authentic video clips based-activities while the second one was exposed to subtitled authentic video clips based- 
activities and one control group that was taught through the conventional teaching . Results showed that using multimedia authentic materials based-activities whether subtitled or nonsubtitled were substantially effective in developing EFL pupils' listening comprehension skills. Also, it was found that subtitled authentic video clips were more effective than non-subtitled authentic video clips in developing listening comprehension.

In a study conducted by Yusuf (2015), the researcher designed a program based on reciprocal teaching strategies to develop secondary students' listening comprehension skills. The sample of the study was 45 students. The researcher adopted the quasi-experimental design where the experimental group followed instruction using proposed program to enhance their listening comprehension skills. The tool of the study was a listening comprehension test. Results proved that there was a statistically significant difference between the mean scores of the experimental group related to reciprocal teaching strategy training in the pretest and posttest in overall and in each sub skill listening comprehension skill favouring the post test.

\section{Reading Comprehension:}

\section{The Current View of the Reading Process:}

It is important to define what reading comprehension is. Simply, it is the process of getting the meaning of the text. Carrell (1988) cited in Nguyen (2007) pointed out that before the 1960s, reading was known as a process of decoding phonemes and was recognized to be attached to listening and speaking. However, by 1965 reading comprehension was described to include mental processing. Thus, schema (cultural knowledge) was examined and assured as an important part in drawing comprehension from reading. After that, the term "psycholinguistic guessing game" was introduced to reading process by Goodman (1971) cited in Nguyen (2007) to refer to the role that prior knowledge plays in making predictions about what readers were going to read. 


\section{The Significance of Reading:}

Reading is a window through which we look at the world .It is a main source for enjoyment and learning. In a growing world of information and science, learners should be fluent readers .Fortunately, most of this information is in English. According to the Directives for General Secondary School Teachers (2012):

"Reading is a major skill which remains readily available for EFL learners through the whole of their lives. Therefore, it has to be stressed / focused upon.." (p.70).

But reading is nothing without comprehension. In this sense, Durkin (1993) viewed reading comprehension the "essence of reading" and is essential for academic and life-long learning.

\section{Types of Reading:}

Reading is regarded as a complex, multi-faceted activity. Richard \& Schmidt (2002) pointed out that different types of reading comprehension are often distinguished, according to the reader's purposes in reading and the type of reading used. The following are commonly referred to:

1. Literal comprehension: reading so as to understand the information that explicitly mentioned in a text.

2. Inferential comprehension: reading to find information which is implicitly mentioned in a text.

3. Critical comprehension: reading to compare information stated with the readers' information.

\section{Reading Strategies:}

\section{Importance of Reading Strategy:}

A host of researchers refer to the importance of reading strategies. For instance, according to Dehnad (2005) cited in Gilani (2012), reading strategy supplies learning chances, facilitates reading and remembering of information in addition to fostering the reading. Adding to this point, Anderson (2003) cited in Karbalaei (2010) saw reading as the interaction between four elements which are the readers, the text, the fluent reading 
and strategic reading. By strategic reading he means that readers have the ability to use a variety of reading strategies to achieve a purpose for reading.

Generally, strategies are known as learning techniques and study skills that facilitate learning (Oxford \& Crookall ,1989). Concerning reading, Dole (2002) clarified that comprehension strategies are routines and procedures which the active reader make use of to improve his/her reading comprehension.

\section{Sub-Categories of Reading Strategies:}

Researchers on reading have different views concerning dividing reading strategies. For example, Mokhtari \& Reichard (2002) mentioned three sub-categories as follows:

1. Global Reading Strategies: They involve some reading strategies directed to a global analysis of text. They include evaluating what to read, guessing what the text is about.

2. Problem-Solving Strategies: They include strategies to solve problems when the passage is difficult. Some of them are re-reading, going back on losing focus, pausing and thinking about reading.

3. Support Reading Strategies: they are the strategies which include use of outside reference materials, taking notes, underlining information.

O'Malley \& Chamot (1989) divided learning strategies into three main categories:

1. Cognitive strategies: They are more related to tasks and learners' active control of learning materials. They involve rehearsing, elaborating, organizing, inferring and summarizing.

2. Metacognitive strategies: They are self-regulatory strategies in which the learner is aware of his/her thinking and can coordinate, monitor, and evaluate learning.

3. Socio/ affective: They involve the interaction with others, like asking questions, asking for clarification etc. 


\section{Theories of the Reading Process}

In general, theories about the reading process are divided into three approaches which are bottom-up approaches, topdown approaches and interactive approaches.

\section{Bottom-up Strategy:}

Harris (2005) referred that the bottom-up (decoding) approach presumes that the passage is essential in the reading process. According to him, readers cannot read if they don't first comprehend the code or the writing system. The principles of this theory postulate that readers tackle the text through first recognizing the smallest units of words. Then, they continually integrate these units into more complex units. For instance, they recognize letters, combine letters to make words, and then they combine words to build up phrases, and then join phrases to make a sentence, sentences to paragraphs and eventually paragraphs to construct the whole text. Readers got meaning along the process but they reach the overall meaning at the end of the process.

\section{Top-down Strategy:}

Readers who employ top-down process resort to their previous knowledge (schemas) to explain a text. Similarly, Rao (2003) briefed that if the readers brings more world-knowledge to the text, they depend less on linguistic information like grammatical, syntactic and semantic clues, consequently, making their reading process more effective. Confirming this viewpoint, Hudson (1982) mentioned that more background knowledge may overcome linguistic weakness.

\section{Interactive Strategy:}

This model suggests that neither bottom-up nor top down models can by themselves account for how reading comprehension occurs. Drawing on this point, Grabe (1991) proposed that both lower-level decoding skills and higher-level interpretation skills can lead to fluent, efficient reading

Also, Bernhardt (1991) concluded that skilled readers can make advantage of bottom-up and top-down models, and 
comprehension is the outcome of an interplay and integration between the two types of processing. Aebersold \& Field (1997) reflected that there are many crucial factors that determine which model to adopt, like the kind of text, readers' background knowledge, language proficiency, and learning aims.

\section{Studies Related to Reading Comprehension:}

Abu-Herz (2016) used some translation strategies to develop EFL secondary stage students' reading comprehension skills. The sample was 70 first year secondary stage students. They were divided into two groups: control group and experimental group. The experimental group was taught reading comprehension through translation strategies, whereas the control group was taught by the conventional way. One instrument was used: a reading comprehension test. Results showed that the experimental group pupils outperformed their counterparts in the control group on the reading comprehension achievement post administration test. In addition, there is a statistically significant difference between pre-and postapplication administration results of the experimental group in the reading comprehension test in favor of the post administration.

Ahmed (2016) examined the effect of semantic mapping strategy and DRTA Strategy in developing secondary school students EFL reading comprehension skills The participants of the this study comprised two experimental groups each $\mathrm{N}=35$ and a control group $(\mathrm{N}=35)$.. The tools included: a reading comprehension skills checklist and a pre-post reading comprehension test. The study findings showed that there were statistically significant differences between the mean scores of the control and the two experimental groups on the post test in overall reading comprehension skills in favour of the two experimental groups. The results revealed that semantic mapping and directed reading thinking activity (DRTA) strategies developed the EFL reading comprehension skills of the participants.The students in the two experimental groups who were taught through using the suggested semantic mapping and DRTA strategies program achieved higher levels of performance. 
Khalil (2016) carried out a study to measure the effect of a graphic organizer- based strategy on developing some EFL reading comprehension skills and reading preferences of preparatory stage students. The sample of the study were 60 girls. They were assigned into experimental and control groups. The researcher adopted the quasi-experimental design where the experimental group followed instruction using the graphic organizer- based strategy to enhance their reading comprehension skills and reading preferences where, students in the control group received their regular instruction .The tools included a reading comprehension test and a reading preferences questionnaire. Results proved that there was a statistically significant difference between the mean scores of the experimental group and the control group on the post administration of both the reading comprehension test and the reading preferences questionnaire favoring the experimental group. Results also revealed that there was a statistically significant difference between the mean scores of the experimental group on the pre- and the post administration of both reading comprehension test and the reading preferences questionnaire favoring the post scores.

\section{Methodology:}

\section{Participants:}

The target population is first year general secondary stage students in a general secondary school for girls during the school year of 2017 / 2018. The sample was derived from "Ahmed Shelbia General Secondary School for Girls" in Manzala Directorate, Dakahlia. Participants were students in first year general secondary stage with age ranging from 14 to 16 years. Two intact groups were selected and randomly assigned to an experimental group $(n=30)$ and a control group $(n=30)$.

\section{Design of the Study:}

The current research adopted the quasi experimental design in terms of using an experimental group and a control one. The experimental group was taught using the CALL 
program, while the control group was taught through the traditional way of teaching suggested in the Teacher's Guide.

\section{Instruments of the Study}

The researcher developed some tools as follows:

\section{The Listening Comprehension Skills Checklist (LCSC):}

\section{Purpose and Source of the LCSC:}

The LCSC aims at determining the most appropriate listening skills for first year secondary stage students. The source of LCSC came from the related literature like Directives for General Secondary School Teachers English Language (20142015), Hassan (2013), and Radwan (2010).The listening comprehension sub-skills questionnaire included forty two subskills. This questionnaire was submitted to a number of EFL teachers and supervisors and to a jury of specialist in ELT to determine the appropriateness of the listening comprehension sub-skills to the sample of the study. They are asked to respond to each skill in accordance with a Likert type scale that ranged from "very suitable", "suitable", "less suitable" to "unsuitable". "Very suitable" was given three marks, "suitable" was given two marks, "less suitable" was given 1 mark and "unsuitable" was given no mark. The jury of specialists agreed on the following top ten sub skills

1. Guessing the meaning of new words from the context.

2. Listening for the main idea.

3. Discriminating among distinctive phonemes.

4. Listening for specific information.

5. Finding the stressed syllable.

6. Distinguishing formal versus informal speech.

7. Detecting key words.

8. Understanding whether speech is polite or rude.

9. Drawing inference.

10. Following instructions and oral directions. 


\section{Validity:}

In order to achieve the validity of the LCSQ, it was submitted to a jury of specialists in ELT .The made some modifications like:

1. Modifying the skill of "Differentiating among distinctive sounds "to "Discriminating among distinctive sounds".

2. Modifying the skill of "knowing key words" to "Detecting key words"

3. Modifying the skill of "Guessing the meaning of words from the context" to "Guessing the meaning of new words from the context"

\section{The Reading Comprehension Skills Checklist (RCSC):}

The RCSQ aims at determining the most appropriate reading skills for first year secondary stage students. The source of RCSC was derived from the related literature as Directives for General Secondary School Teachers English Language (20142015) ,Eissa (2009) and Mohamed (2009)It was submitted to a number of EFL teachers and supervisors and to a jury of specialists in TEFL to determine the appropriateness of the reading comprehension sub-skills to the sample of the study. They were asked to respond to each skill in accordance with a Likert type scale that ranged from "very suitable", "suitable", "less suitable" to "unsuitable". The jury of specialists agreed on the following top ten sub skills.

1. Guessing meaning of new vocabulary from context.

2. Identifying referents for pronouns.

3. Finding the main idea in a passage.

4. Agreeing/Disagreeing with the given opinions.

5. Understanding cause/effect relationship.

6. Infer factual information and certain ideas.

7. Arranging the details and in a logical order.

8. Selecting the topic sentence of a paragraph.

9. Drawing conclusions from the author's words. 
10. Identifying the author's purpose.

\section{Validity}

In order to achieve the validity of the questionnaire, it was submitted to a jury of specialists in ELT. They made some modifications like:

1. Modifying the skill of "Knowing of word meaning to" Knowing word meaning"

2. Modifying the skill of "Answering literal questions to" answering questions"

3. Omitting the skill of "Knowing that words may have more than one meaning"

\section{The Pre/Post Listening Comprehension Test:}

\section{Aim of the Test:}

It was to used measure the level of the students in the control group at reading comprehension before being subjected to the traditional method and the level of the students in the experimental group before being subjected to the CALL program .Once again, the two groups were subjected to the same test after the experimentation to measure any development at reading comprehensions skills. The pre- test was administered at the beginning of the first term in the school year 2016/ 2017.

\section{Source of the Pre / Post Listening Comprehension Test:}

It was constructed in the light of the following:

1. The results of the listening comprehension skills checklist (RCSC)

2. Reviewing the related literature concerning listening comprehension.

\section{Description of the Pre / Post Listening Comprehension Test:}

It consists of three listening texts with 25 questions. The questions of the test were based on the light of the selected ten listening comprehension skills. Each question was assigned one mark. Different types of questions were used: choose the correct 
answer, circle the word you hear in the following words and follow the directions given by the teacher.

\section{Validity and Reliability of the Pre / Post Listening Comprehension Test:}

Validity and reliability of the pre / post listening comprehension test were established before administering it to the study sample.

\section{Administering the Test}

The pre- test was administered to both the experimental group and the control one at the beginning of the first term in the school year 2016 / 2017. The results of pre- test were subjected to statistical treatment to find whether there is a statistically significant difference between the two groups before the experimentation. Therefore, $t$-test for independent samples was used to compare the means of the two groups. The same test was administered again to both the experimental group and the control at the end of the first term in the school year 2016 / 2017.

\section{The Pre/Post Reading Comprehension Test:}

\section{Aim of the Test}

It was to used measure the level of the students in the control group at reading comprehension before being subjected to the traditional method and the level of the students in the experimental group before being subjected to the CALL program Once again, the two groups were subjected to the same test after the experimentation to measure any development at reading comprehensions skills. The pre- test was administered at the beginning of the first term in the school year 2016/ 2017.

\section{Source of the Pre / Post Reading Comprehension Test}

It was constructed in the light of the following:

1. The results of the reading comprehension skills questionnaire (RCSC)

2. Reviewing the related literature concerning reading comprehension. 


\section{Description of the Pre / Post Reading Comprehension Test}

It consists of three passages with 25 questions. The questions of the test were based on the light of the selected ten reading comprehension skills. Each question was assigned one mark.

\section{Validity and Reliability of the Pre / Post Reading Comprehension Test}

Validity and reliability of the pre / post reading comprehension test were established before administering it to the study sample.

\section{Administering the Test}

The pre- test was administered to both the experimental group and the control one at the beginning of the first term in the school year 2016 / 2017. The results of pre- test were subjected to statistical treatment to find whether there is a statistically significant difference between the two groups before the experimentation. Therefore, $\mathrm{t}$-test for independent samples was used to compare the means of the two groups' .The same test was administered again to both the experimental group and the control at the end of the first term in the school year 2016 / 2017.

\section{The Intervention: the CALL Program}

\section{Aims of the CALL Program}

Generally, the CALL program aims at improving reading comprehension skills and listening comprehension skills of first year general secondary stage students.

\section{Piloting the Program}

After the modification of the program, it was piloted in two sessions to face any problems that might arise while administering it .

\section{Implementing the program}

The program was carried out within about three months, two periods (45 minutes) a week. The sessions included an 
introductory session where the researcher gave instruction to participants on how to use the program and a final session to listen to their comments

\section{Teacher's role}

Throughout the program, the teacher was present in all sessions, but he mostly assumed the role of an observer, a guide and a facilitator.

\section{Results and Discussion}

\section{Analysis of Pretest Results}

Pre-tests were administered to have baseline data about the participants' actual level. Therefore, $t$ test for independent samples was run. (Table 2) shows the results.

Table (2)Comparing the Performance of the Experimental Group and the Control Group on the Pre-Listening Test and Pre-Reading

Test

\begin{tabular}{|c|c|c|c|c|c|c|}
\hline \multirow{2}{*}{ Skills } & \multicolumn{2}{|c|}{$\begin{array}{c}\text { Experimental } \\
\text { group }\end{array}$} & \multicolumn{2}{|c|}{ Control group } & \multirow{2}{*}{ Sig. } \\
\cline { 2 - 5 } & Means & SD & Means & SD & & \\
\hline Listening & 12.3 & 3.05 & 13.13 & 3.2 & - & \multirow{2}{*}{ Not } \\
\hline Reading & 11.53 & 2.6 & 10.8 & 3.1 & .97 & Not \\
\hline
\end{tabular}

(Table 2) shows that the t-values are insignificant in the pre reading test and pre listening test .That is, the two groups' scores on the tests items were relatively the same. i.e. the students' level was the same in both groups. Therefore, the equivalence between the groups was determined.

\section{Analysis of Posttest Results}

\section{Analysis of the First Hypothesis Results}

In order to test the First hypothesis - there is a statistically significant difference between the mean scores of the experimental group and those of the control group on the post test of listening comprehension favoring the experimental group - a t test for independent samples was run. (Table 3) shows the results. 
Table 3Comparing the Performance of the Experimental Group and the Control Group on the Post-Listening Test.

\begin{tabular}{|c|c|c|c|c|c|c|c|}
\hline \multirow{2}{*}{$\begin{array}{c}\text { Reading } \\
\text { comprehension } \\
\text { subs-kills }\end{array}$} & \multicolumn{2}{|c|}{$\begin{array}{l}\text { Experimental } \\
\text { group } \\
\end{array}$} & \multicolumn{2}{|c|}{$\begin{array}{c}\text { Control } \\
\text { group }\end{array}$} & \multirow[b]{2}{*}{$t$} & \multirow{2}{*}{$\eta^{2}$} & \multirow[t]{2}{*}{$\eta^{2}$} \\
\hline & Means & SD & $\begin{array}{c}\text { Mean } \\
\text { s }\end{array}$ & SD & & & \\
\hline $\begin{array}{l}\text { Guessing the } \\
\text { meaning of words } \\
\text { from the context }\end{array}$ & 2.5 & .69 & 1.9 & 1.1 & $2.46^{*}$ & .09 & $\begin{array}{c}\text { Mediu } \\
\text { m } \\
\text { effect }\end{array}$ \\
\hline $\begin{array}{c}\text { Listening for the } \\
\text { main idea }\end{array}$ & 2.13 & .82 & 1.10 & .88 & $4.69^{*}$ & .28 & $\begin{array}{l}\text { Large } \\
\text { effect }\end{array}$ \\
\hline $\begin{array}{l}\text { Distinguishing } \\
\text { formal versus } \\
\text { informal speech }\end{array}$ & 1.97 & .85 & 1.27 & .78 & $3.31^{*}$ & .16 & $\begin{array}{l}\text { Large } \\
\text { effect }\end{array}$ \\
\hline $\begin{array}{l}\text { Listening for } \\
\text { specific } \\
\text { information }\end{array}$ & 1.80 & .48 & 1.13 & .73 & $4.17^{*}$ & .23 & $\begin{array}{l}\text { Large } \\
\text { effect }\end{array}$ \\
\hline $\begin{array}{l}\text { Detecting key } \\
\text { words }\end{array}$ & 1.63 & .49 & .97 & .67 & $4.4^{*}$ & .25 & $\begin{array}{l}\text { Large } \\
\text { effect }\end{array}$ \\
\hline $\begin{array}{c}\text { Understanding } \\
\text { whether speech is } \\
\text { polite or rude }\end{array}$ & 1.93 & .25 & 1.43 & .68 & $3.8^{*}$ & .20 & $\begin{array}{l}\text { Large } \\
\text { effect }\end{array}$ \\
\hline Drawing inference & 1.03 & .72 & .53 & .57 & $2.98^{*}$ & .13 & $\begin{array}{c}\text { Mediu } \\
\text { m } \\
\text { effect }\end{array}$ \\
\hline $\begin{array}{c}\text { Finding the } \\
\text { stressed syllable }\end{array}$ & 2.63 & .61 & 1.7 & 1.18 & $3.84^{*}$ & .20 & $\begin{array}{l}\text { Large } \\
\text { effect }\end{array}$ \\
\hline $\begin{array}{c}\text { Discriminating } \\
\text { among distinctive } \\
\text { phonemes }\end{array}$ & 2.77 & .50 & 1.53 & .94 & $6.35^{*}$ & .41 & $\begin{array}{l}\text { Large } \\
\text { effect }\end{array}$ \\
\hline $\begin{array}{c}\text { Following } \\
\text { instructions and } \\
\text { oral directions }\end{array}$ & 1.83 & .46 & 1 & .64 & $5.77^{*}$ & .36 & $\begin{array}{l}\text { Large } \\
\text { effect }\end{array}$ \\
\hline Whole test & 20.2 & 2.75 & 12.6 & 4.4 & 8.1 $^{*}$ & .53 & $\begin{array}{l}\text { Large } \\
\text { effect }\end{array}$ \\
\hline
\end{tabular}

Note. * Significant at $\alpha=0.05$

According to (Table 3$)$, The experimental group $(M=20.2$, $S D=2.75)$ scored significantly higher than the control group $(M$ $=12.6, S D=4.4), t(58)=8.1, p=.00<0.05$. The effect size was measured by eta squared $\left(\eta^{2}\right)$. It was .53 indicating a large effect of the program. Also, the t-values in all the sub-skills were statistically significant.

The improvement in the listening comprehension can be attributed to the pre-reading, during reading and post reading sections, which served as pre listening activities to the listening section. The students in the experimental group become familiar with the text through interaction with it. They already grasped 
the meaning of new words, knew the key sentences and had a visualization of the text in their mind. Consequently, this experience with the text led to a better understanding of the text when they listened to it.

Moreover, the students in experimental group had advantages over the control group via some options in the CALL program. For example, the treatment students had the options to pause, stop and replay the audio, which the students in the control group lacked. More importantly, they had the option to listen to the text in the presence of the text or not. Thus, the spoken text became audible and readable at the same time. The findings are in tune with Mahmoud (2015).

\section{Analysis of the Second Hypothesis Results}

In order to test the second hypothesis - there is a statistically significant difference between the mean scores of the experimental group and those of the control group on the post test of reading comprehension favoring the experimental groupa t test for independent samples was run. (Table 4) shows the results.

According to (Table 4), the experimental group $(M=15.1$, $S D=4.8)$ scored significantly higher than the control group $(M$ $=9.3, S D=2.7), t(58)=5.75, p=.00<0.05$. The effect size was measured by eta squared $\left(\eta^{2}\right)$. It was .36 indicating a large effect of the CALL program.

The pre reading stage gave the students in the experimental group the chance to interact with pre reading activities such as pre questions, pictures, graphic organizer and key sentences easily. Also, the graphic organizer provided the students with a visualization of the target text, which aided them to organize the content of the passage and their ideas by creating connections between information. All of these activities supplied the experimental group students with relevant background knowledge that facilitated comprehending the text.

In the during reading section, the students in the experimental group used annotations which provided them with 
the intended meaning needed in the passage immediately. In addition to the required definition, they can look at the pictures of the new words which appear with definitions. Moreover, the students heared the pronunciations of new words, which can accelerate the speed of reading leading to a better comprehension of the text.

Table (4)Comparing the Performance of the Experimental Group and the Control Group on the Post-Reading Test.

\begin{tabular}{|c|c|c|c|c|c|c|c|}
\hline \multirow{2}{*}{$\begin{array}{l}\text { Reading } \\
\text { comprehension } \\
\text { subs-kills }\end{array}$} & \multicolumn{2}{|c|}{$\begin{array}{l}\text { Experimenta } \\
\text { l group }\end{array}$} & \multicolumn{2}{|c|}{$\begin{array}{l}\text { Control } \\
\text { group }\end{array}$} & \multirow{2}{*}{$t$} & \multirow{2}{*}{$\eta^{2}$} & \multirow{2}{*}{$\eta^{2}$} \\
\hline & Means & SD & Means & SD & & & \\
\hline $\begin{array}{c}\text { Guessing } \\
\text { meaning of new } \\
\text { vocabulary from } \\
\text { context } \\
\end{array}$ & 2.3 & .76 & 1.46 & .90 & $\begin{array}{c}4.04 \\
*\end{array}$ & 0.22 & $\begin{array}{l}\text { Large } \\
\text { effect }\end{array}$ \\
\hline $\begin{array}{l}\text { Identifying } \\
\text { referents for } \\
\text { pronouns }\end{array}$ & 2.53 & .68 & 1.6 & .77 & $\begin{array}{c}4.97 \\
*\end{array}$ & .30 & $\begin{array}{l}\text { Large } \\
\text { effect }\end{array}$ \\
\hline $\begin{array}{l}\text { Finding the main } \\
\text { idea in a passage }\end{array}$ & 1.87 & .94 & .57 & .63 & $\begin{array}{c}6.32 \\
*\end{array}$ & .41 & $\begin{array}{l}\text { Large } \\
\text { effect }\end{array}$ \\
\hline $\begin{array}{l}\text { Agreeing/Disagr } \\
\text { eeing with the } \\
\text { giving opinions }\end{array}$ & 2.23 & .77 & 1.47 & .86 & 3.63 & 0.19 & $\begin{array}{c}\text { Mediu } \\
\text { m } \\
\text { effect }\end{array}$ \\
\hline $\begin{array}{l}\text { Understanding } \\
\text { cause/effect } \\
\text { relationship }\end{array}$ & 1.93 & .83 & 1.73 & .74 & $.99 \#$ & .02 & $\begin{array}{c}\text { No } \\
\text { effect }\end{array}$ \\
\hline $\begin{array}{c}\text { Infer factual } \\
\text { information and } \\
\text { certain ideas }\end{array}$ & .53 & .68 & .17 & .38 & $\underset{*}{2.58}$ & .10 & $\begin{array}{l}\text { small } \\
\text { effect }\end{array}$ \\
\hline $\begin{array}{l}\text { Arranging the } \\
\text { details and in a } \\
\text { logical order }\end{array}$ & .40 & .62 & .47 & .57 & $\underset{\#}{.043}$ & .0 & $\begin{array}{c}\text { No } \\
\text { effect }\end{array}$ \\
\hline $\begin{array}{l}\text { Selecting the } \\
\text { topic sentence of } \\
\text { a paragraph }\end{array}$ & 1.20 & .76 & .40 & .56 & $\underset{*}{4.63}$ & .27 & $\begin{array}{l}\text { Large } \\
\text { effect }\end{array}$ \\
\hline $\begin{array}{l}\text { Drawing } \\
\text { conclusions from } \\
\text { the author's } \\
\text { words }\end{array}$ & 1.07 & .78 & .57 & .50 & $\underset{*}{2.94}$ & .13 & $\begin{array}{c}\text { Mediu } \\
\text { m } \\
\text { effect }\end{array}$ \\
\hline $\begin{array}{l}\text { Identifying the } \\
\text { author's purpose }\end{array}$ & 1 & .83 & .83 & .79 & $.08^{\#}$ & .01 & $\begin{array}{c}\text { No } \\
\text { effect }\end{array}$ \\
\hline Whole test & 15.1 & 4.8 & 9.3 & 2.7 & 5.75 & .36 & $\begin{array}{l}\text { Large } \\
\text { effect }\end{array}$ \\
\hline
\end{tabular}

Note. ${ }^{*}$ Significant at $\alpha=0.05$ 
This quick and essay access of the multimedia features in the program didn't interrupt the process of reading unlike the control group students who had to look up the meaning of new words in the paper dictionary and choose the right entry from many entries, which is a time consuming and interruptive to the reading process. Furthermore, the computerized glosses were designed in a way that these three features don't appear until the students hover over the new words and they appeared above the text so as to keep the whole passage visible. More importantly, all the features in this interactive multimedia program were designed to ensure the interactivity on the side of the students with the text. The findings of the present study are consistent with the findings of previous studies that proved that learners can develop their vocabulary through multimedia annotations to enhance reading comprehension: Ali (2016) and Hamed (2016).

\section{Conclusion}

The current research examined the impact of a CALL program on improving reading comprehension skills and listening comprehension skills of first year secondary stage students. To achieve this aim, the researcher developed some tools: A reading comprehension test, a listening comprehension test. The sample was two intact groups (60 students). They were randomly selected and equally divided into an experimental group and a control group. Both groups were pre-tested. After ensuring their equivalence, the experimental group students were taught reading and listening using the CALL program, while the control group students were taught according to conventional way. After teaching the program, both groups were post- tested using the same instruments used in the pre-testing. Results of the study showed significant differences between the mean scores of the experimental group and those of the control group on the post listening comprehension test and post reading comprehension test in favour of the experimental group.

\section{Recommendations}

In light of the results of the present study, the following recommendations seem to be pertinent. 
First, policy makers should:

1. Consider using computers in Testing English in Egyptian schools.

2. Strongly bear in mind that English courses in Egyptian schools must be introduced through portable computers and tablets in the classroom instead of moving the class to the computer lab in the school.

3. Provide sufficient training for in-service teachers on how to use CALL.

4. Computerize EFL courses in Egypt or providing teachers and students with CDs that can be attached to the English courses.

5. Supply schools in Egypt with the latest computer sets with the latest software versions.

Second, faculties of educations should

1. Train pre service teachers practically on how to use CALL.

2. Train pre service teachers on electronic lesson planning.

3. Increase the teaching of CALL in their courses for pre service teachers.

Third, Egyptian teachers should

1. Make use of the exiting potentialities in schools to use CALL.

2. Motivate their learners to use call in and outside their schools.

3. Develop themselves to keep up with the latest technology advances in education.

Finally, it is hoped that the results of this study will inspire all those who are interested in education in Egypt to speed up the integration of call in Egyptian schools.

\section{Suggestions for Further Research}

Researchers may need to:

1. Investigate the effect of CALL programs on developing other aspects of language like translation and speaking. 
2. Examine the effect of using annotations with mother tongue meanings on developing vocabulary acquisition and reading comprehension.

3. Conduct more studies to examine the impact of CALL on teaching reading comprehension among primary and preparatory stages learners.

4. Carry out researches to examine of effectiveness of CALL all to enhance learners' autonomy.

5. Carry out future studies on teachers' attitudes towards using CALL.

6. Carry out more researches to examine the difficulties encountering using CALL in Egyptian schools and how to overcome them.

\section{References}

Abdelhafez, A. (2006). The effect of a suggested training program in some metacognitive language learning strategies on developing listening and reading comprehension of first year EFL students (Unpublished master's thesis). Faculty of Education, Minia University.

Abou -Herz, S. (2016). Using some translation strategies to develop EFL secondary stage students' reading comprehension skills. (Unpublished master's thesis), Faculty of Education, Mansoura University.

Aebersold, J.A. \& Field, M.L. (1997). From reader to reading teacher. Retrieved December 13, 2012 from the WWW at : http://eltj. oxfordjournals. org/content /59/4/355.extract Ahmadi, M. (2011). A study of factors affecting EFL learners' English listening comprehension and the strategies for improvement.(Master thesis). Retrieved from http://ojs. academ ypublisher .com/index.php/ jltr/article/ download /0205977988/3567.

Ahmed, A. (2016). The effectiveness of semantic mapping strategy and DRTA strategy in developing secondary school students EFL reading comprehension skills (Unpublished doctoral dissertation), Faculty of Education, Ain Shams University. 
Ali, E. (2016).The effectiveness of a proposed (call) program indeveloping the preparatory students' EFL vocabulary and grammar learning and motivation (Unpublished doctoral dissertation). Faculty of Education, Mansoura University.

Al-Ammary, A. (2015). The effectiveness of a program based on "podcasting" in developing some EFL listening comprehension skills among preparatory school students. (Unpublished master's thesis). Hurghada Faculty of Education, South Valley University.

Bax S. (2003). CALL - past, present and future. System 31(1), 1328.

Beatty, K. (2003). Teaching and researching computer-assisted languagelearning. New York: Longman.

Bernhardt, E. B. (1991). Reading and development in a second language: Theoretical, empirical, and classroom perspectives. Norwood, NJ: Ablex.

Boyle, E. (1993)::An Alternative Approach to Improving Listening Skills.English Teaching Forum, 31(3), 1-12.

Buck, G. (2001). Assessing listening. Cambridge:Cambridge University Press.

Campbell, A. (2003).Weblogs for use with ESL classes. The Internet TESL Journal, 9 (2), 10-12.

Davies G. \& Higgins J. (1985). Using computers in Language Learning: A Teacher's Guide, London: CILT.

Directives for Secondary School EFL Teachers, (2014).ELT Counseller's Office . Ministry of Education, Egypt.

Dole, A.(2002).Comprehension strategies. Retrieved from https: //www.mheonline. com/treasures /pdf/ jan_dole_cs.

Durkin, D. (1993). Teaching them to read, sixth ed. Allyn \& Bacon, Boston, MA.

Egbert, J. (2005).CALL essentials: Principles and practice in call classrooms.

Eissa, S. (2009). The effectiveness of a proposed media news program in developing reading comprehension and attitudes towards reading among first year secondary students (Unpublished master's thesis), Faculty of Education, Tanta University. 
Gilani, M. (2012). Impacts of learning reading strategy on students' reading comprehension proficiency. http://www. scribd.com/doc/154086341/Reading-for-Read-Compr

Grabe, W. (1991): Current Developments in Second Language Reading Research. TESOL Quarterly. 25 (3): 375-406.

Hamed, M. (2016).The impact of a proposed web-based unit to enhance hello! 3 reading comprehension skills for Al-Azhar preparatory institute students. (Unpublished master's thesis), Faculty of Education, Mansoura University.

Hardisty, D. \& Windeatt, S. (1989). CALL, Oxford: Oxford University Press.

Harris, P. (2005). Reading in the primary school years. Retrieved from http://books.google .co. za/books?id. Accessed on 28 June 2009.

Hassan, H. (2013). The effectiveness of audio-assisted reading strategy on enhancing EFL prep students listening and reading comprehension (Unpublished master's thesis). Faculty of Education, Mansoura University.

Hudson, T. (1982). The effect of induced schemata on the shortcircuit in 12 reading: non-decoding factors in 12 reading performance. Language Learning 32, 1-31.

Ismail, A. (2016). The effect of educational blogs on developing reading comprehension skills in English as a foreign language for the second year preparatory school students (Unpublished master's thesis) Faculty of Education, Helwan University.

Karbalaei, K. (2010). Iranian EFL and Indian ESL college students' beliefs about reading strategies in 12 . Retrieved August 8, 2013 from the WWW at: http://www.revistas. unal.edu. co/ index.php/ profile/article/ view/17671/ 36818

Khalil , A. 2016. The effect of a graphic organizer-based strategy on enhancing some EFL reading comprehension skills and reading preferences of preparatory stage. (Unpublished master's thesis), Faculty of Education, Zagazig University.

Leuf, B., \& Cunningham, W. (2001). The wiki way: Quick collaboration on the web. Upper Saddle River, New Jersey: Addison-WESLey 
Levy, M. (1997). CALL: Context and conceptualization. Oxford: Oxford University Press.

Mahmoud, W., (2015).using multimedia authentic materials based activities to develop EFL listening comprehension skills of preparatory stage students. (Unpublished master's thesis). Faculty of Education, Mansoura University.

Mattar, H. (2006). The use of some teaching strategies to enhance reading comprehension and written response to text (Unpublished master's thesis). Faculty of education, Zagazig University.

Mendelsohn, D. J. (1994). Learning to listen: A strategy-based approach for the second language learner. San Diego: Dominie Press.

Mohamed, S. (2009).The effectiveness of motivational strategies in developing engineering students' reading comprehension skills (Unpublished master's thesis). Faculty of Education, Zagazig University.

Mokhtari, K., \& Reichard, C. (2002). assessing students' metacognitive awareness of reading strategies. Journal of Educational Psychology, 94(2), 249-259.

Nguyen, T. (2007).The impact of background knowledge and time constraint on reading comprehension of Vietnamese learners of English as a second language. Retrieved from http://opensiuc. lib.siu. edu/ cgi/viewcontent.cgi?article= 1939\&context=theses

O'Malley, J. M. \& Chamot, A. U. (1989). Listening cmprehension strategies in second language acquisition. Applied Linguistics, 10(4): 418-437.

O'Reilly, T. (2005). What is web 2.0. design patterns and business models for the next generation of software. Retrieved from http://oreilly.com/web2/archive/what-isweb-20.html

Oxford, R. \& Crookall, D. (1989). Research on six situational language learning strategies: methods, findings, and instructional issues. Modern Language Journal, 73(4) 404419.

Prensky, M.. (2000). Digital game-based learning. New York: McGraw-Hill 
Radwan, S. (2010).Using the dictogloss strategy for developing some EFL listening comprehension skills among secondary school students (Unpublished master's thesis), Faculty of Education, Benha University.

Rao, Z. (2003). Effect of using a top-down strategy on Chinese university students comprehension of English readings. Asian Journal of English Language Teaching, 13, 29-44.

Richard, J. \& Schmidt, R. (2002).Longman dictionary of language teaching and applied linguistics. Third Edition. Pearson Education

Rost, M. (1994). Introducing listening. London: Penguin Group. Underwood, M. (1989). Teaching listening. London: Longman.

Valarmathi. K. E (2011). Mobile assisted language learning. Retrieved from https://sites. google.com/site/ journal of technologyforelt/archive/april2011/mobileassisted language learning>

Warschauer, M. (1996) .Computer assisted language learning: An Introduction. In Fotos, S. (ed.) Multimedia language teaching, Tokyo: Logos International.

Warschauer, M \& Healey, D. (1998).Computers and language learning: An Overview. Language Teaching, 31(2) 57-71

Yusuf, M. (2015).The effectiveness of using reciprocal teaching strategies for developing secondary students' listening comprehension skills (Unpublished master's thesis). Faculty of Education, Ainn Shams University. 
